\title{
Adult Inmates' Motivation for Participation in Educational Programs in Greece
}

\author{
Vasiliki Papaioannou ${ }^{1}$, Evaggelos Anagnou ${ }^{1} \&$ Dimitris Vergidis $^{1,2}$ \\ ${ }^{1}$ Hellenic Open University, Patra, Greece \\ ${ }^{2}$ University of Patras, Hellenic Open University, Patra, Greece \\ Correspondence: Vasiliki Papaioannou, Hellenic Open University, Patra, Greece. Tel: 30-69-0621-6026. E-mail: \\ vanpap2008@gmail.com
}

Received: February 16, 2018

doi:10.5539/ies.v11n6p132
Accepted: March 23, $2018 \quad$ Online Published: May 29, 2018

URL: https://doi.org/10.5539/ies.v11n6p132

\begin{abstract}
Adult Education in prisons aims at challenging the illiteracy of those incarnated, which often leads to delinquency and recidivism. In Greece there are educational programs designed for inmates like those of vocational training and counseling. With the establishment of Second Chance Schools (SCS) inside prisons, a more systematic and integrated effort was made for the overall development of trainees and their fullest participation in the economic, social and cultural life. In the past, little interest had been shown regarding the education of adult inmates. Lately, however, many studies have been conducted regarding the work that SCS provide. For this reason, a systematic review of the relevant bibliography and a compilation of the findings of the studies realized between 2006-2016, regarding the motives of inmates participating in the educational programs, was considered appropriate. The results demonstrate that the strongest motives have to do with the pains of imprisonment, the reduction of time the inmates had to serve, the enrichment of knowledge of the inmates, their self-improvement and the ability to acquire and develop essential skills for their rehabilitation in the societal and professional world.
\end{abstract}

Keywords: adult education, adult inmates, education in prisons, motives for participation in educational programs

\section{Introduction}

Educational activities and programs take place in Greece in various prisons and by various agencies. The operation of Second Chance Schools for adults in prisons is an important development, as the curriculum they offer is based on the principles of adult education and contributes to raising the prisoners' education level. Several researchers have studied parameters of these educational actions at the level of one prison or prisons in one region. However, no synthesis of the findings of these individual surveys has been attempted so far.

The contribution of our work to the field lies in the fact that it is a systematic review in the field of prison education in Greece in order to synthesize the data of individual surveys on the motivation of prisoners to participate in training programs carried out in prison. It is important to consider the issue of prisoners' motivation for learning, in order to properly design the relevant educational activities and programs.

Altogether, seventeen (17) investigations have emerged from our search for this particular issue.

The first two sections present the theoretical framework of the work, focusing on adult education, the training of prisoners and the conceptual identification of motivations. The third part concerns the methodological framework of the work and the fourth the presentation of the results. The paper ends with the discussion and the conclusions.

\section{Adult Education and Inmates' Education}

Adult education is a field of activity, but also a scientific field, clearly described within the context of lifelong learning and education, at least in the scientific discourse (Karalis, 2013, p. 15).

We quote UNESCO's classic definition (UNESCO, 1976):

The term 'adult education'denotes the entire body of organized educational processes, whatever the content, level and method, whether formal or otherwise, whether they prolong or replace initial education in schools, colleges and universities as well as in apprenticeship, whereby persons regarded as adult by the society to which they belong develop their abilities, enrich their knowledge improve their technical or professional qualifications or turn them in a new direction and bring about changes in their attitudes or behavior in 
twofold perspective of full personal development and participation in balanced and independent social, economic and cultural development. (p. 2)

Kokkos $(2005$, p. 45) states that the institutional field of adult education “... consists of the actors that provide the full range of forms of formal and non-formal adult education".

Later, the wider term of lifelong education appeared, which, according to Vergidis (2001)

is an approach to all educational activities (formal, non-formal and informal) of all levels, allowing their composition in an educational continuum, in constant interplay with the socio-economic, political and cultural reality. Lifelong education is characterized by flexibility in time, space, content and teaching techniques. (p. 138)

Gradually the term lifelong learning predominates internationally, as being broader than the terms "lifelong education" and "adult education". According to the definition in a relevant European Commission resolution (Council of the European Union, 2002):

Lifelong learning must cover learning from the pre-school age to that of post-retirement, including the entire spectrum of formal, non-formal and informal learning. Furthermore, lifelong learning must be understood as all learning activity undertaken throughout life, with the aim of improving knowledge, skills and competences within a personal, civic, social and/or employment-related perspective. (p. 11)

As it has been pointed out, the replacement of the term 'lifelong education' with the term 'lifelong learning' also marks the shift towards individualization in the context of neo-liberal ideological hegemony (Vergidis, 2014).

Lifelong Learning (LLL) has been a priority of European education policy, but also of the advanced world, since the late 1990s onwards. The reasons for LLL's dominance are, according to Green (2006, p. 19), three framework factors that act as driving forces (a) demographic and aging populations found in all advanced societies; (b) global economic restructuring and its impact on skills demand; and (c) cultural and social change in developed countries.

However, it is clear that lifelong adults' education strengthens the under education-over education dipole by widening educational inequalities (Vergidis, 2014; General Secretariat for Lifelong Learning, 2013). One of the key findings in UNESCO's international conference on adult education - held every twelve years - COFINTEA VI of 2009 was that in fact those with lower levels of education benefit less from adult education. As it is emphatically pointed out, this is the "fatal problem" that adult education policy has to face, by devoting significant resources to non-privileged people (UNESCO, 2009).

Among the non-privileged are, of course, as a vulnerable group, the inmates.

Attempts to educate inmates in our country's prisons have been carried out in the past by the Prefectural Committees of Population Education and by the General Secretariat for Adult Education (formerly General Secretariat for Adult Education, now General Secretariat for Lifelong Learning and Youth), which has initiated counseling programs since 1985, alongside educational programs, aimed at enhancing educational motivation, cultivating skills for better management of life both while in prison and after it, acquisition of social skills and personal empowerment (Rigoutsou, 2005).

Also, since August 2003, within the framework of the project "Adult Education Centers", classes of prisoners' training operated in specific prisons in the country in order to create those conditions that can provide the right opportunities for entering the labor market, reducing social exclusion and shaping the attitude of an active citizen through the acquisition of new basic skills, as well as the upgrading and updating of already existing ones (Rigoutsou, 2005). However, these programs functioned in particular prisons, not all prisoners had access to them, and they were fragmentary and were carried out on a voluntary basis. It is noted that the operation of the Adult Education Centers stopped in June 2011.

Actions are also undertaken by Non-Governmental Organizations, which in cooperation with Vocational Training Centers carry out programs in various prisons in the country (Moudatsou, n.d.).

In addition, KETHEA, in the context of its actions for the detoxification of people from psychotropic substances, operates educational programs in many judicial prisons in the country (Papaioannou, 2015).

A significant landmark was the operation in 2004 of the first Second Chance School (SCS) in Greek prisons, specifically in the Judicial Prison of Larissa. Since then, their number has increased gradually and in 2017-2018 there are eleven SCS in total in the following detention facilities: Diavaton Thessaloniki, Nigrita, Grevena, Trikala, Larissa, Eleonas Thebes, Domokos, Malandrinos, Patras, Chania, Korydallos. In addition, there is a department at the Korydallos Detention Hospital (Ministry of Education, Research and Religious Affairs/General Secretariat for Lifelong Learning and Youth / Foundation for Youth and Lifelong Learning, 2017). 
The operation of these schools is an important development in prison education, as their curriculum is based on the principles of adult education and is developed taking into account the specific characteristics-social, cognitive and psychological- of the prisoners (Papaioannou, Anagnou, \& Vergidis, 2016). The training provided in the SCSs is systematic and leads to high school certificate. The duration of the studies is two years and is divided into two nine-month periods. A cornerstone of the education offered is a multiliteracies network that aims at the acquisition of modern knowledge, skills and attitudes that will help trainees with social and economic integration and advancement. An important role is played by trainers who are called upon to perform a particularly demanding and complex task (Rigoutsou, 2005; Wright, 2005; Papaioannou, Anagnou, \& Vergidis, 2016).

\section{Motivation: Conceptual Identification}

It is important to initially identify the concept of motivation. Motive is defined as what moves, pushes or drives the person into action. In more detail, "the instincts, impulses, various purposes, desires, or various emotional states act as internal causes of behavior, while wages, lusts or fears or repulsive irritations are the external causes" (Kostaridou-Efclidi, 1999, p. 17). As it has been pointed out, "Motivation theories vary and are one of the most important points of inquiry into the factors that motivate learners to interrupt an adult education program" (Vergidis et al., 2013, p. 7).

The variety of motivation is such that no single theory is sufficient either to describe them or to interpret the mechanisms through which they affect human experience, behavior and action. For example, Spector (2000) argues that motivation is an internal process that activates, guides and maintains behavior over time, intensifying and directing it under the effect of needs and desires. McClelland (1961) and Atkinson (1964) developed the theory of achievement motivation, defining motive as drive, that is, an inner need and a desire to experience success that forces individuals into action. Moreover, when the person knows that the decision to act includes reward, then the motivation to achieve it acts multiplicatively. De facto positive and negative feelings accompany this decision. The positive ones create the expectation of success and the negative fear of failure (Kostaridou-Efclidi, 1999). According to Rubenson (1977), a relationship of agreement or inconsistency arises between participation and expectation of this participation.

Kandas (1998, p. 40) considers motives as result of a direct or indirect hetero-determination, in the sense of "creating the conditions that might make someone do something". According to the self-determination theory, motives may be endogenous and / or exogenous (Ryan and Deci, 2000): endogenous motivation exists when one is mobilized to satisfy an internal need, while exogenous motivation exists when one is driven into action expecting a result which is directly linked to the action taken. Rogers (1999) defines motivation for learning as a person's tendency to pursue learning activities that are important and directed towards a particular goal, clarifying that "motivation is linked to the ability to approach the goal: close goals-high level of motivation, distant goals-weak motivation" (p. 130).

Boshier, creator of the Educational Participation Scale (EPS), did not focus only on the types of trainees with their characteristics, but also on the motivation for participation based on their orientations (Boshier, 1971; Boshier, 1973; Boshier \& Collins, 1985 as cited in Karalis, 2013), which are grouped as follows: a. developing social relations, b. external expectations, c. social offer; d. professional upgrading; e. escape from other situations; and f. interest in knowledge. Burgess (1971) identified motivation as "the desire for knowledge, for the attainment of a personal goal, the attainment of a social goal, the attainment of a religious objective, escape, participation in an activity, and compliance with formal requirements", p. 3).

Regarding prisoners in particular, their motivation to participate in training activities is partly different from the motives of the general population (Costelloe, 2003; Forster 1990).

The initial impetus for prisoners to be included in an educational activity in prison should be linked to educational factors that rarely apply outside of prison (Forster, 1990). Some of their incentives to participate in education only apply in the context of prison. They emerge from the need to 'escape' from the prison life, or alternatively, prepare for life after release (Costelloe, 2003; Parson \& Lagerback 1993). According to these findings, education is not always attractive on its own, but prisoners can get involved in the educational process to avoid something less attractive, such as jail work.

Similarly, Skaalvik, Finbak, and Pettersen (2003) identified a broad category of prisoners who began participating in educational programs to avoid aspects of prison life as opposed to seeking education as a constructive activity, while in another broad category prisoners cited as the greatest motivation the value of education and future employment prospects.

In a more recent study three categories of motivators were identified (Manger, Eikeland, Diseth, Hetland, \& 
Asbjørnsen, 2010):

- Preparing for life after release

- Social reasons

- Factors related to the general context of prison.

In their study, Manger, Eikeland, and Asbjørnsen (2013), summarizing the bibliography, conclude that educational decisions among prisoners are based on various motives, which can be both inherent and exogenous. Inmates may be motivated to build up competencies or have a desire to start learning for learning per se or motivated by forces other than education itself, such as worries about the future (e.g. work or the desire to avoid crime) or the desire to be with others at school. They can also be mobilized by escaping from something less desirable, such as life routine in jail and boredom.

\section{Research Methodology}

The present work is a systematic review in the field of prison education. According to the manuals for researchers by the Cochrane (2015) and Cambell (2014) organizations, in order for a review to be considered systematic, it should satisfy some principles when designing and implementing it. In brief, we present the principles of the methodological steps of the research process in the systematic review, which were followed in this study:

- Formulation of the research question. Our research question was: What are the trainee inmates' motivation for taking part in educational programs?

- Defining the criteria for searching and selecting the material to be studied Defining the criteria for the inclusion and exclusion of primary studies.

- Thorough search and identification of the studies to be included in the analysis based on the research question.

- Full and detailed report on the material and methods of collecting and analyzing both quantitative and qualitative data.

- Synthesis of the results.

\subsection{Search Method}

Initially, a search for sources of material collection was conducted. Since this systematic review concerns the training of adult inmates in Greece, we searched in national databases and search engines, article references, abstracts of papers in conference proceedings, databases of doctoral and postgraduate dissertations. More specifically, Google Scholar, online libraries of Greek universities - including the Hellenic Open University - and the National Documentation Center were used. In cases where the material was not available electronically with open access, the file was searched for in the libraries' premises or the full text order service was used wherever possible. Also, articles published in scientific journals, such as "Adult Education", the "Aretha" Scientific Yearbook, or on scientific websites such as the Adult Education Network of Crete have been searched for. Finally, there was a personal communication with a researcher to locate research that could not be retrieved in any other way.

The systematic review was conducted between 20th April 2017 and 5th June 2017. The search resulted in 44 titles in Greek ( 3 doctoral theses, 37 postgraduate dissertations and 4 articles). At the initial screening, 41 of them were identified as potentially relevant, requiring a full text review in order to select the review studies. After being studied systematically, the researches which converged on the research question were selected. Thus, we resulted in 17 studies, which investigated the issue of inmates' motivation for participating in educational programs. 16 of these are postgraduate diploma theses and 1 is an article.

\subsection{Data Record and Analysis}

Key elements of the identity of the analyzed researches are illustrated in the following Table: 
Table 1 . The identity of the researches

\begin{tabular}{lllcc}
\hline Author & Time & Place & Sample & Methodology \\
\hline Papadaki & 2006 & Women's Prison of Korydallos & $10 \mathrm{M}$ & $\begin{array}{c}\text { Qualitative } \\
\text { Qualitative and } \\
\text { Quantitative }\end{array}$ \\
Gravalou & 2010 & Larissa SCS & $32 \mathrm{M}(10 / 22)$ & Quantitative \\
Papathanasiou, N. & 2010 & Judicial Prison of Diavata & $52 \mathrm{M}$ & Quantitative \\
Petsas & 2010 & Korydallos SCS & $10 \mathrm{M}$ & Qualitative \\
Iliopoulou & 2011 & Domokos SCS and Elaionas SCS & $16(8 \mathrm{M}-8 \mathrm{~F})$ & Qualitative \\
Kouimtzi & 2011 & $3^{\text {rd }}$ SCS of Thessaloniki & $11 \mathrm{M}$ & Qualitative \\
Orlis & 2013 & Diavata SCS and Korydallos SCS & $57(55 \mathrm{M}-2 \mathrm{~F})$ & Qualitative \\
Panteleri & 2014 & Diavata SCS & $10 \mathrm{M}$ & Quantitative and \\
Papathanasiou, H. & 2014 & Larissa SCS & $83 \mathrm{M}(80 / 3)$ & qualitative \\
Papaioannou & 2015 & Korydallos SCS & $18 \mathrm{M}$ & Qualitative \\
Chrysikopoulou & 2015 & Women's Prison of Elaiona & $20 \mathrm{~F}$ & Quantitative \\
Sakka & 2015 & Korydallos SCS & $7 \mathrm{M}$ & Qualitative \\
Korella & 2016 & Grevena SCS & $14 \mathrm{~F}$ & Qualitative \\
Mousiou & 2016 & Korydallos SCS & $72 \mathrm{M}$ & Qualitative \\
Barbakos & 2016 & Korydallos SCS and Grevena SCS & $32 \mathrm{M}(16+16)$ & Qualitative \\
Stouri & 2016 & Korydallos SCS & $28 \mathrm{M}$ & Qualitative \\
Touloumi & 2016 & Elaionas SCS & $15 \mathrm{~F}$ & Qualitative \\
\hline
\end{tabular}

Note. $\mathrm{M}=$ Men, $\mathrm{F}=$ Female, SCS=Second Chance School. The triangulation method was used in the researches of Gravalou (2010) and Papathanasiou (2014). As a result, the results obtained are classified, according to the research tool, as quantitative or qualitative ones.

As shown in Table 1, out of a total of 17 surveys, one is of 2006, three of 2010, two of 2011, one of 2013, two of 2014 , three of 2015, and five of 2016. The total sample of trainees in the systematic review is 487 inmates, of which 442 are men and 45 are women. Of the seventeen surveys, the eleven were developed with qualitative methodology, the four with quantitative, while the two with mixed (quantitative and qualitative).

On the basis of the above methodological approaches, as listed in Table 1, they were grouped together. The surveys in which the research tool used was a questionnaire with closed-ended questions were classified as quantitative. If a questionnaire with open questions was used, they were classified as qualitative. Specifically, the analysis of the data for quantitative approach surveys was as follows: Responses were entered as a whole on a spreadsheet of the Microsoft Office Excel 2007 software.

For qualitative surveys, content analysis was selected as a data processing method. We chose to make the following distinction in qualitative surveys: a) purely qualitative, b) quantified qualitative.

\section{Results}

The following procedure was followed in the recording of the results: Initially the individual results of the quantitative surveys are presented, then the results of the quantified qualitative and, finally, of the purely qualitative ones.

\subsection{Motivation for Participating In Educational Programs: Results of Quantitative Surveys}

The quantitative surveys in which the incentives to participate in educational programs were investigated are six in total (Gravalou, 2010; Papathanasiou, 2010; Papathanasiou, 2014; Chrysikopoulou, 2015; Musiou, 2016; Stouri, 2016) and the total sample of trainees in these surveys is are 274 inmates. Following are the results (Table 2 and Figure 1). 
Table 2. Motivation for participating in educational programs (results of quantitative surveys)

\begin{tabular}{lc}
\hline Categories/Subcategories & Number of Trainees \\
\hline 1. Relief from the prison's suffering & 420 \\
1.1.Escape from the suffocating prison's environment & 102 \\
1.2. Avoidance of routine & 94 \\
1.3. Creative use of lost time & 82 \\
1.4. Communication with non - prisoners & 60 \\
1.5. Social interaction & 55 \\
1.6. Personal pleasure & 22 \\
1.7. Avoiding inertia of the mind & 5 \\
2. Education & 308 \\
2.1. Acquisition / improvement of knowledge and skills (in general) & 141 \\
2.2. Thirst for learning & 75 \\
2.3. Improvement of writing skills & 50 \\
2.4. Improvement of speaking skills & 42 \\
3. Qualifications & 273 \\
3.1. Social and professional reintegration & 160 \\
3.2. Certificate acquisition & 64 \\
3.3. Continuation of studies & 49 \\
4. Reduction of imprisonment time & 131 \\
("wages") & 122 \\
5. Self-improvement & 47 \\
5.1. Changing the way of thinking & 47 \\
5.2 Confidence & 28 \\
5.3 Personal fulfillment & 109 \\
6. Other motivation & 45 \\
6.1. Encouragement from the personal environment & 31 \\
6.3. Positive experience from previous education & 33 \\
7. Utilitarian motivation (proof of good conduct) & 54 \\
N = 274 (Note that some trainees reported more than one category / subcategory) \\
\hline
\end{tabular}

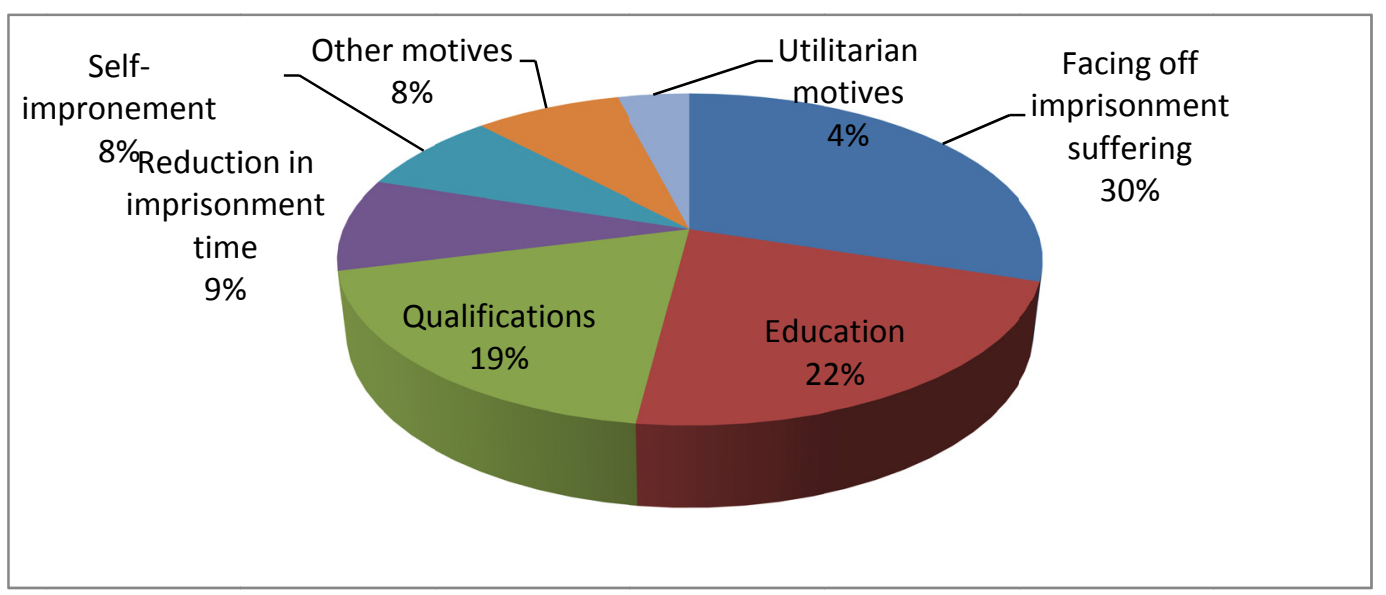

Figure 1. Motivation for participating in educational programs (results of quantitative surveys)

$30 \%$ of the inmates reported relief from the prison's suffering as the strongest motivation for participation in education programs. Most of the recordings refer to escape from the suffocating prison's environment, the avoidance of routine, the creative use of lost time and social interaction, especially with non-prisoners. There are several references to the inmates' need to do something from which they will receive personal pleasure. The issue of mind alertness is of great concern to them.

Attending an educational program is not only a matter of psycho-emotional motivation; it is also a logical decision. 
Thus, a high percentage refers to the motivation for education (22\%). Most trainees report the acquisition or improvement of knowledge and skills in general as a motivation for participate, while many focus on improving their writing and speaking skills. The rest, in a more emotional account of their speech, report the thirst for learning. In accordance with the aforementioned motivation and as a follow-up, the incentive to acquire qualifications is also recorded (19\%). Inmates perceive the value of acquiring an important asset, such as a degree. Their participation seems to be mainly related to their social and professional reintegration.

$9 \%$ of the respondents report the beneficial calculation of the penalty (the so called "wages") as motivation to participate in educational programs. The only exception is women in the Chrysikopoulou's (2015) survey, in which no research participant mentions "wages" as an incentive.

Personal improvement is yet another important motivation for inmates (8\%). By specifying the concept of self-improvement, there are reports of changing the way of thinking, acquisition of confidence and need for personal fulfillment.

In a percentage of $8 \%$ they report other incentives, such as encouragement from personal environment or friendship with other prisoners attending an educational program, as well as the positive experience from attending an educational program.

Of course, and this is perfectly reasonable, there are also incentives of utilitarian nature. Respondents at a percentage of $4 \%$ consider that attending an educational program will lead to favorable treatment by the court.

\subsection{Motivation for Participating In Educational Programs: Results of Quantified Quantitative Surveys}

The results of the surveys using the quantified qualitative method are listed below (Table 3 and Figure 2). The sample is 116 participants.

Table 3. Motivation for participating in educational programs (results of quantified quantitative surveys)

\begin{tabular}{lc}
\hline Categories/Subcategories & Number of Trainees \\
\hline 1. Relief from the prison's suffering & 80 \\
1.1. Escape from the suffocating prison's environment & 33 \\
1.2. Creative use of lost time & 17 \\
1.3. Avoidance of routine & 12 \\
1.4. Communication with non - prisoners & 6 \\
1.5. Social interaction & 6 \\
1.6. Psychological balance & 3 \\
1.7. Avoiding inertia of the mind & 3 \\
2. Reduction of imprisonment time & 43 \\
("wages") & 39 \\
3. Education & 19 \\
3.1. Acquisition / improvement of knowledge and skills (in general) & 9 \\
3.2. Thirst for learning & 8 \\
3.3. Learning Greek & 3 \\
3.4. Improvement of reading and writing skills & 25 \\
4. Qualifications (High School Certificate) & 13 \\
5. Utilitarian motivation & 8 \\
5.1. Proof of good conduct & 5 \\
5.2. Avoidance of moving to another prison & 3 \\
6. Self-improvement & \\
N=116 (Note that some trainees reported more than one category / subcategory)
\end{tabular}




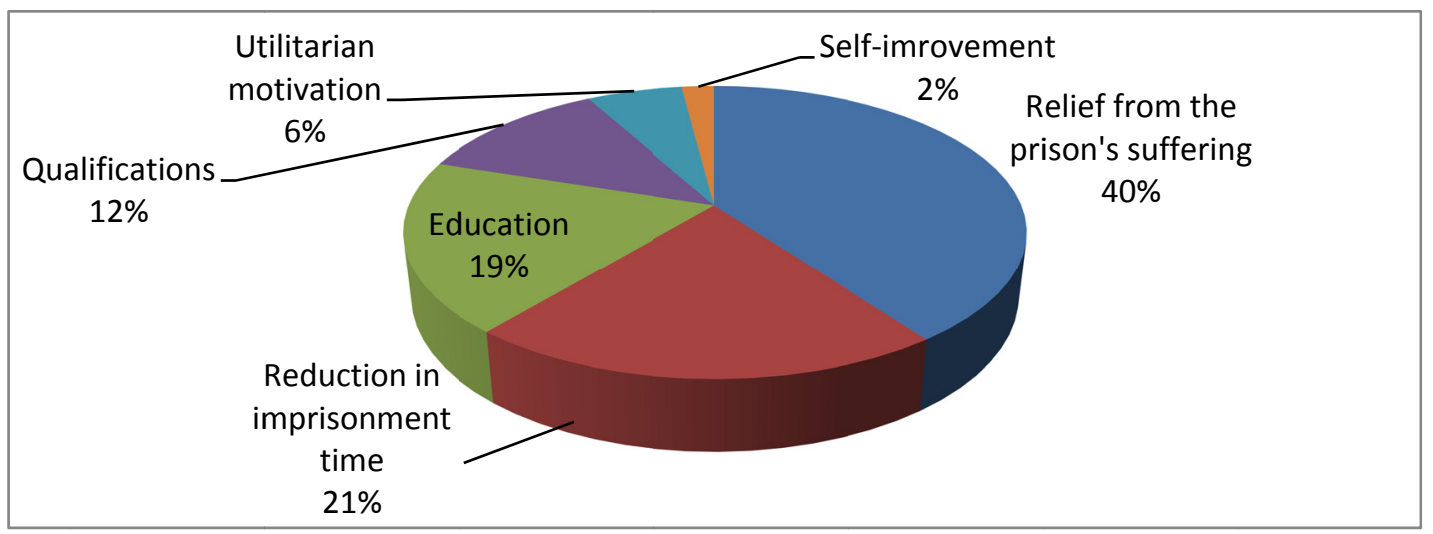

Figure 2. Motivation for participating in educational programs (results of quantified quantitative surveys)

The majority of the inmates report escapes from the suffocating prison's environment as their dominant motivation to participate in education programs $(40 \%)$. This finding confirms the finding of the quantitative surveys. Following are the incentive of reduction in imprisonment time (21\%), education (19\%), acquisition of qualifications (12\%), utilitarian motivation (6\%) and self-improvement $(2 \%)$.

\subsection{Motivation for Participating In Educational Programs: Results of Quantitative Surveys)}

Finally, we present the results of qualitative research, six in number, in which there is no quantitative measurement (Papadakis, 2006; Gravalou, 2010; Iliopoulou, 2011; Korella, 2016; Barbakos, 2016; Touloumi, 2016). Altogether, 97 trainees participated in these surveys. In Table 4 we present the results of these surveys.

Table 4. Motivation for participate in educational programs (results of quantitative surveys)

\begin{tabular}{|c|c|c|c|c|c|c|}
\hline Motivation & 1 & 2 & 3 & 4 & 5 & 6 \\
\hline A. Reduction in imprisonment time & $\sqrt{ }$ & $\sqrt{ }$ & $\sqrt{ }$ & $\sqrt{ }$ & $\sqrt{ }$ & $\sqrt{ }$ \\
\hline \multicolumn{7}{|l|}{ B. Relief from the prison's suffering } \\
\hline B1. Escape from the suffocating prison's environment & $\sqrt{ }$ & $\sqrt{ }$ & $\sqrt{ }$ & & $\sqrt{ }$ & \\
\hline B2. Creative use of lost time & & & & $\sqrt{ }$ & $\sqrt{ }$ & \\
\hline B3. Communication with non - prisoners & & & $\sqrt{ }$ & $\sqrt{ }$ & $\sqrt{ }$ & \\
\hline B4. Social interaction & & & $\sqrt{ }$ & & & \\
\hline B5. Personal pleasure & $\sqrt{ }$ & & $\sqrt{ }$ & & & \\
\hline \multicolumn{7}{|l|}{ C. Education } \\
\hline C1. Acquisition / improvement of knowledge & $\sqrt{ }$ & $\sqrt{ }$ & $\sqrt{ }$ & $\sqrt{ }$ & $\sqrt{ }$ & $\sqrt{ }$ \\
\hline C2. Acquisition of social education & & & & $\sqrt{ }$ & & \\
\hline C3.Learning Greek & & & & $\sqrt{ }$ & $\sqrt{ }$ & \\
\hline \multicolumn{7}{|l|}{ D. Qualifications } \\
\hline D1. High school certificate & & & $\sqrt{ }$ & $\sqrt{ }$ & $\sqrt{ }$ & $\sqrt{ }$ \\
\hline D2.Continuation of studies & & & & & $\sqrt{ }$ & \\
\hline D3. Social and professional reintegration & & & $\sqrt{ }$ & $\sqrt{ }$ & $\sqrt{ }$ & \\
\hline \multicolumn{7}{|l|}{ E. Self-improvement } \\
\hline E1.Personal improvement & & & $\sqrt{ }$ & $\sqrt{ }$ & $\sqrt{ }$ & $\sqrt{ }$ \\
\hline E2. Quality of life improvement & & & & & $\sqrt{ }$ & \\
\hline \multicolumn{7}{|l|}{ F. Other motivation } \\
\hline F1. Subsidy & $\sqrt{ }$ & & & & & \\
\hline
\end{tabular}

Note. Numbers 1, 2, 3, 4, 5, 6 correspond to the surveys in the order mentioned above.

In these surveys as well, all inmates reported as a motivation for participation the reduction of imprisonment time, the so called "wages", either as primary or secondary motivation. In the Papadakis's (2006) survey, female prisoners report an additional incentive, the subsidy they receive because they attend vocational training programs.

Also, the incentive attracting all trainees is that of relief from the prison's suffering, with similar records to both quantitative and quantified qualitative surveys. 
All trainees recognize their educational 'poverty', so they all report as their motivation the acquisition or improvement in knowledge. For foreigners, motivation is the opportunity given to learn the Greek language. Others report the need for social education that is conquered through social interaction in a pedagogical environment.

The high school certificate and the resulting benefits are an additional incentive for inmates to get involved in the educational process.

Finally, the inmates' need to improve in a personal level and to improve their quality of life when released from prison is an additional incentive for them.

\section{Discussion and Conclusions}

The results of the qualitative surveys are in full harmonization and reinforce the results deriving from both quantitative surveys and quantified qualitative surveys. At the same time, they are also supported by the relevant literature.

More specifically, the following main conclusions have emerged from the previous analysis, regarding the main motives mentioned by the inmates for their participation in educational programs:

Relief from the prison's suffering: Confinement is the greatest traumatic experience for people who are punished in this way for their delinquent behavior. In prison they experience deprivation of liberty and autonomy, deprivation of goods and services, as well as of personal security (Sykes, 1958). The institutionalization, marginalization and subculture of the prison, to which Toch (1975) refers, create a suffocating environment from which inmates want to escape. Participating in educational programs gives them this possibility to a great extent, as is shown in the results of all surveys.

Education: Although this finding may surprise, the reality is that the overwhelming majority of prisoners have a low educational attainment (Barbatakos, 2010; Spinelli, 2009; Vacca, 2004; Theophilos, 2004) and the fact that they are given the opportunity to acquire or to improve pre-existing knowledge and skills in prison, is extremely important to them. Trainees seem to recognize that under-education is the cause of their unemployment (see also Vergidis, 1995, p. 14) and perhaps of their offending behavior. They believe that they can prepare for life after release (Costelloe, 2003, p. 131) and hope that they will be able, by acquiring knowledge and skills, to open new horizons in their lives. Several also specify their response by stating that they want to improve their writing and speaking skills.

In addition, many inmates report being thirsty for learning and this can be considered normal, as most have dropped out of education for reasons beyond their will. This is confirmed by many surveys (Vergidis, 2004; Vergides et al., 2007).

Reduction in imprisonment time: The so-called "wages" are an important incentive to participate in an education program. Most likely, when prisoners are informed that they are gaining two days' penalty for each day of attending the education program, they seek attendance. Besides, as Manger et al. (2010) report, education alone cannot be an incentive if other incentives do not exist. This finding is found in every survey with small hierarchical differentiations: other respondents report it as a dominant motivator and some others as secondary.

Acquisition of qualifications: The desire for acquiring a school qualification has a positive impact on the attendance and completion of an educational program. Trainees in prison are expecting the certificate to provide them with a "legitimized opportunity for social advancement and be a springboard for differentiated access possibilities" (Ladritsi, 2007, p. 112). This finding is confirmed by Loewen (1997) as well, who highlights preparation for release and continuity of education as the most important motivation for education in prison. Darkenwald and Merriam (1982) report that adult learners are offered the opportunity to successfully negotiate transitions from their social roles (worker, parent etc.).

Self-improvement: It appears that the trainee inmates believe they can change their way of thinking so that they do not engage again in delinquent behavior. Recurrence is their fear and they feel that with education they can defeat their "evil" selves. Also, inmates bearing the stigma of the prisoner which is for most of them a deep sense of shame, they believe that by attending an educational program, they can regain their self-esteem. This finding is also confirmed in research conducted at international level: Parker (1990) states that participation in educational programs increases the inmates' self-esteem. Furthermore, many trainee inmates report that they seek personal fulfillment and obviously mean that by engaging in creative activities they will be given the opportunity to cultivate and develop the positive aspects of their personality. This report is confirmed by Kett (1995) as well.

The remark that needs to be made is that there are differences only in the hierarchy of motivations, which must be 
considered perfectly normal, because each person has his / her personal perspective when entering a process, in this case the educational process.

There is also a difference in the hierarchy of findings between qualitative and quantitative surveys. An emerging interpretation of this differentiation may be the research tools used, since there are different epistemological principles behind qualitative and quantitative methods. In particular, "The philosophical roots of qualitative research belong to naturalistic philosophies, while quantitative research to the positivistic. The two approaches have a different starting point on the ontological-cognitive level, i.e. regarding the nature of reality" (Saravfidou, 2011, p. 17).

It appears that when starting their studies, their motivation for participating mainly concerns their daily difficulties and the situation they are in. But later on, they prioritize education and their greatest desire is to continue their studies either because they think their social and professional rehabilitation will be easier, or because they want to prove to themselves and their environment that they are "others", or because education "won" them. The "I would like" at the beginning of their studies in the educational programs later becomes "I want", "I can".

With this systematic review we have attempted to obtain a more comprehensive picture about the motivation of adult trainee inmates in Greece to participate in educational programs. The methodological constraint is that we have looked at surveys that have been carried out in Greece and can be found in databases. We believe, however, that it is a useful contribution to future researchers in the field of adult prisoners' education, as well as to a better understanding of the field so that the relevant educational policy can be more effectively defined. In particular, the findings can help improve the planning of future interventions, so that educational programs are more effective, responding to inmates' motivations. It would be interesting to research in the future whether the inmates' participation in educational programs contributes to their reintegration after their release.

\section{References}

Atkinson, J. W. (1964). An introduction to Motivation. Princeton, NJ: Van Nostrand.

Barbakos, A. (2016). Educational Needs and Barriers to Learning in Second Chance Schools (SCS) of Correctional Centers of Larissa and Grevena (Master's thesis, Library Hellenic Open University).

Burgess, P. (1971). Reasons for Adult Participation in Group Educational Activities. Adult Education, 22(1), 3-29. https://doi.org/10.1177/074171367102200101

Cambell Collaboration. (2014). Systematic Reviews: Policies and Guidelines (Version 1.2). Retrieved from https://www.campbellcollaboration.org/media/k2/attachments/campbell_policies_and_guidelines.pdf

Cochrane Collaboration. (2015). Cochrane Handbook for Systematic Reviews of Interventions (Version 5.1). Retrieved from http://training.cochrane.org/handbook

Costelloe, A. (2003). Third level education in Irish prisons: Who participates and why? (Doctoral thesis, Milton Keynes: The Open University).

Council of the European Union. (2002). The resolution on 27 June 2002 for lifelong learning (2002/C 163/01). Official Journal of the European Communities.

Darkenwald, G. G., \& Merriam, S. B. (1982). Adult Education. Foundations of practice. New York: Harper and Row.

Forster, W. (1990). The higher education of prisoners. In S. Duguid (Ed.), Yearbook of correctional education 1990 (pp. 3-43). Burnaby: Institute for the Humanities, Simon Fraser University.

General Secretariat for Lifelong Learning. (2013). National Lifelong Learning Program 2013-2015. Strategic Framework. Athens: Ministry of Education and Religious Affairs, Culture and Sport/General Secretariat for Lifelong Learning.

Gravalou, A. (2010). Investigating the views of adult trainee inmates on the teaching techniques applied at Second Chance School in Judicial Prisons of Larissa (Master's thesis, Library Hellenic Open University).

Green, A. (2006). The many aspects of lifelong learning: modern trends in education policy in Europe (Translation Moutsios, S.). In A. Kapsalis, \&A. Papastamatis (Eds.), Professionalism in Continuing Education (pp.15-42). Athens: Typothito-G. Dardanos.

Hiliopoulou, V. (2011). Motives for participation and attitudes of trainees in SCS Central Greece prisons (Master's thesis, Library Hellenic Open University).

Hrysikopoulou, E. (2015). The implementation and use of participatory-active adult education training 
techniques in Second Chance Schools. Views of trainees attending the SCS of Eleonas women's prison in Thiva (Master's thesis, Library Hellenic Open University).

Kantas, A. (1998). Organizational-Industrial Psychology (Part 1). Athens: Greek Letters.

Karalis, T. (2013). Motives and barriers to adult participation in lifelong learning. Athens INE GSEE \& IME GSEVEE.

Kett, M. (1995). Survey of prisoners' attitudes to education. Wheatfield Place of Detention.Unpublished report.

Kokkos, A. (2005). Adult Education. Detecting the field. Athens: Metehmio.

Korella, A. (2016). Motives for participation and perceptions of trainnees in the 1st SCS (Prison) of Grevena (Master's thesis, Library Hellenic Open University).

Kostaridou-Efklidi, A. (1999). Motives Psychology. Athens: Greek Letters.

Kouimtzi, K. (2011). Investigation of motivation, intentions and trainees-inmates expectations within the General Detention Center of Thessaloniki - 3rd Second Chance School of Thessaloniki (Master's thesis). Library Hellenic Open University.

Landritsi, J. (2007). Trainees of Second Chance Schools: Research on the characteristics and their cultural capital in SCS Patras, Pyrgos and Agrinio (Master's thesis, Faculty of Primary Education, School of Social and Human Sciences, University of Patras).

Loewen, J. R. (1997). Transition to the Community: Prison Literacy Programs and Factors Which Lead to Success in the Community. Prepared for Human Resources Development Canada, National Literacy Secretariat. Brandon, Manitoba: John Howard Society of Brandon, Inc. Retrieved from http://www.nald.ca/library/research/transitions/cover.html

Manger, T., Eikeland O.-J., Diseth, A., Hetland, H., \& Asborjornsen, A. (2010). Prison Inmates' Educational Motives: Are They Pushed or Pulled? Scandinavian Journal of Educational Research, 54(6), 535-547. https://doi.org/10.1080/00313831.2010.522844.

Manger, T., Eikeland, O.-J., \& Asbjørnsen, A. (2013). Effects of Educational Motives on Prisoners' Participation in Education and Educational Desires. European Journal on Criminal Policy and Research, 19(3), 245-257. https://doi.org/10.1007/s10610-012-9187-x

McClelland, D. C. (1961). The achieving society. New York: The Free Press. https://doi.org/10.1037/14359-000

Ministry of Education, Research and Religious Affairs/General Secretariat for Lifelong Learning and Youth/Foundation for Youth and Lifelong Learning. (2017). Call for expressions of interest in the selection of educational staff with service contract, at Second Chance Schools (SCS) school year 2017-2018. Athens: 07-08-2017.

Moudatsou, M. (n.d.). Imprisonment and release. Retrieved from http://www.epimelitesanilikon.gr/pdf/ Moudatsou.pdf

Mousiou, A. (2016). Participation motives of vulnerable social groups in Adult Education programs. The case of Korydallos Prison (Master's thesis, Library Hellenic Open University).

Orlis, S. (2013). The needs for career counseling of vulnerable social groups: the case of SCS trainees in Diavata and Korydallos Correctional Centers (Master's thesis, Library HOU).

Panteleri, A. (2014). The views of vulnerable social groups on their education programs: The case of Second Chance School in Diavata Prison (Master's thesis, Library Hellenic Open University).

Papadaki, V. (2006). Study on the education, training and employment of prisoners in the context of their social reintegration. The case of the Central Prisoner of Korydallos (Master's thesis, Library Hellenic Open University).

Papaioannou, V. (2015). The views of inmates in Korydallos prison for their education at the Second Chance School (Master's thesis, Library Hellenic Open University).

Papaioannou, V., Anagnou, E., \& Vergidis, D. (2016). Inmates' Adult Education in Greece-A Case Study. International Education Studies, 9(10), 70-82. https://doi.org/10.5539/ies.v9n10p70

Papaioannou, V., Anagnou, E., \& Vergidis, D. (2016). The role of the adult inmates trainer-A Case Study. Educ@tional cycle, 4(2), 41-60.

Papathanasiou, I. (2015). Investigating views of trainee inmates on attendance at the Second Chance School.A 
Case Study: The Second Chance School of the Prison of Larissa (Master's thesis, Library Hellenic Open University).

Papathanasiou, N. (2010). Correctional education. The example of the Second Chance School Diavata Thessaloniki (Master's thesis, Aristotle University of Thessaloniki).

Parker, E. A. (1990). The Social-Psychological Impact of a College Education on the Prison Inmate. Journal of Correctional Education, 41(3), 140-146.

Parson, M., \& Langenback, M. (1993). The reasons prisoners indicate they participate in prison education programs: another look at Boshier's PEPS. Journal of Correctional Education, 44, 38-41.

Petsas G. (2010). Inmates Training: The Second Chance School in Korydallos prison. Adult Education, 34, $31-41$.

Rigoutsou, H. (2005). Inmates Councelling. Athens: IDEKE. Ministry of Education, EPEAEK 2, Measure 1.1. Act 1.1.2., Act 1.1.2V. Retrieved from http://repository.edulll.gr/132

Rogers, A. (1999). Adult Education ( $\mu \tau \varphi$. M. Papadopoulou, M. Tomprou). Athens: Metehmio.

Rubenson, K. (1977). Participation in recurrent education. A research review. Paper presented at meeting of National Delegates on Development in Recurrent Education. Paris.

Ryan, M., \& Deci, L. (2000). Intrinsic and extrinsic motivations: Classic definitions and new Directions. Contemporary Educational Psychology, 25, 54-67. https://doi.org/10.1006/ceps.1999.1020

Sakka, V. D. (2015). The Right to Prison Training: Case Study in the Close Prison in Patra (Master's thesis, Athens: University of Athens, School of Education, Department of Early Childhood Education \& University College London, Institute of Education). Joint program postgraduate studies "Education and Human Rights".

Sarafidou, G.-O. (2011). Articulation of quantitative and qualitative approaches. Athens: Gutenberg.

Skaalvik, E. M., Finbak, L., \& Pettersen, T. (2003). Undervisning i fengsel. På rett kjøl? [Prison education. On an even keel?]. Bergen: Fylkesmannen i Hordaland, Utdanningsavdelinga.

Spector, P. (2000). Industrial and Organizational Psychology: Research and Practice. New York: John Wiley \& Sons Inc.

Spinelli, K. (2009). The inter-institutional training counteracts the risk factors for redicivism? Proceedings of the conference presentation on: The education in prisons: Rehabilitation Lever. Athens 05/09/2009. Retrieved from http://www.epea.org/epeahellas

Stouri, V. (2016). Career counseling for adult prisoners (Master's thesis, Library Hellenic Open University).

Sykes, G. H. (1958). The society of captive: A study of maximum security prison. Princeton: Princeton University.

Theophilou, P. (2004). The professional preparation and integration of people at risk of social exclusion: young ex-prisoners (Unpublished master's thesis). Athens: Panteion University.

Toch, H. (1975). Men in crisis: Human breakdowns in prison. New York: Aldine.

UNESCO. (1976). Recommendation on the development of adult education. Adopted by the General Conference at its nineteenth session, Nairobi, 26 November 1976. Paris: Unesco.

UNESCO. (2009). Rapport mondial sur l'appentissage et l'education des adultes. Resume analytique. Hamburg: UNESCO Institute for Lifelong Learning, CONFINTEA VI.

Vacca, J. S. (2004). Educated Prisoners are less likely to Return to Prison. The Journal of Correctional Education, 55(4), 297-305.

Varvatakos, N. (2010). Correctional education. Magazine As if... a prisoner. March-April-May 2010.

Vergidis, D. (1995). Undereducation. Social, political and cultural dimensions. Athens: Ypsilon/Books.

Vergidis, D. (2001). Lifelong learning and education policy. In K. P. Haris, N. V. Petroulakis, S. Nikodimos (Eds.), Continuing Education and Lifelong Learning (pp.127-144). Athens: Atrapos,

Vergidis, D. (2004). Second Chance Schools: School paths and expectations of trainees. In L. Vekris $\varsigma$, \& E. Hodolidou (Eds.), 1st Panhellenic Conference of Second Chance Schools, Panteion University (pp. 381-399). 28-29 June 2003 Athens, GSAEPEPTH/GGEE/IDEKE.

Vergidis, D. (2014). Lifelong learning and educational inequalities. InA. Kyridis (Ed.), Vulnerable social groups 
and lifelong learning (pp. 121-150). Athens: Gutenberg.

Vergidis, D., Asimaki, A., Tzintzidis, A. (2007). Correctional education. The Second Chance School of Korydallos Prison. Arethas Scientific Yearbook, Volume IV, 61-93. Patras: University of Patras, School of Humanities and Social Sciences, Primary Education, pp. 61-89.

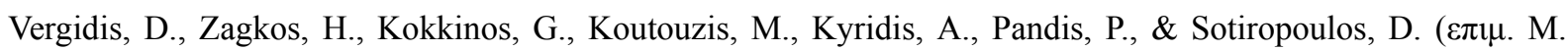
Koutouzis) (2013). Drop out from structures of adult lifelong learning. Athens: Center for the Development of Educational Policy of General Confederation of Greek Labor.

Wright, R. (2005). Going to teach in prisons: Culture shock. The Journal of correctional education, 56(1), 19-38.

Touloumi, A. (2016). Education in prison: learning motives, barriers and the role of adult trainer in prisons. The case of inmates in SCS at Eleonas women's prison in Thiva (Master's thesis, Library Hellenic Open University).

\section{Copyrights}

Copyright for this article is retained by the author(s), with first publication rights granted to the journal.

This is an open-access article distributed under the terms and conditions of the Creative Commons Attribution license (http://creativecommons.org/licenses/by/4.0/). 